Al-Manhaj: Journal of Indonesian Islamic Family Law, 1 (2), 2019: 86-96

ISSN: 2715-003; E-ISSN 2714-5514

DOI: http://dx.doi.org/10.19105/al-manhaj.v1i2.3075

\title{
Historis Waris Jahiliyah dan Awal Islam
}

\author{
Ali Wahdi \\ (Institut Agama Islam Negeri Madura, Jl. Raya Panglegur km. 04 \\ Pamekasan-69311, Jawa Timur, Indonesia)
}

\begin{abstract}
Abstrak:
Sebagian aturan syariat Islam, siapapun yang wafat dari kalangan ummat islam dan empunyai tirkah atau harta peninggalan, maka harta tersebut harus diwariskan. Hal itu sudah menjadi ketentuan dalam syari'at islam yang di atur ketat dalam hukum warits, sehingga dalam masalah hukum warits ini pelakunya harus mengikuti ketentuan-ketentuan yang sudah di teteapkan baik dari sisi poenerima waritsan ataupun dari sisi pembagian waritsan. Dalam Makalah ini penulis akan mengupas tuntas dinamika hokum warits tepatnya pada masalah kewarisan Islam dari sisi historiografi Islam, hal itu mencakup sejarah dalam kewarisan Islam, kewarisan pada masa jahiliyah (pra-islam), kewarisan pada masa awal Islam, serta peletakkan dasar hukum kewarisan Islam. Untuk itu maka dapat dapat diketahui permasalahan permasalahan yang ada dalam kewarisan Islam, seperti sebab-sebab menerima warisan, halangan menerima warisan dan hak-hak sebelum pembagian warisan. (As the rules of Islamic law, anyone who dies from among the Islamic Ummah and has a tirkah or inheritance, the property must be inherited. That has become a provision in Islamic sharia which is strictly regulated in the law of warits, so that in the case of warits law, the perpetrators must follow the provisions that have been set both in terms of the receipt of waritsan or in terms of distribution of waritsan. In this paper the author will explore thoroughly the dynamics of the law warits precisely on the issue of Islamic inheritance in
\end{abstract}


terms of Islamic historiography, it includes history in Islamic inheritance, inheritance in the period of ignorance (pre-Islamic), inheritance in the early days of Islam, and laying the foundation of Islamic inheritance law . For that reason, it can be known the problems that exist in Islamic inheritance, such as the reasons for receiving inheritance, barriers to receiving inheritance and rights before inheritance distribution.)

\section{Kata Kunci:}

Historis; Waris; Jahiliyah; Awal Islam

\section{Pendahuluan}

Pada dasarnya, semua manusia mau tidak mau harus mengikuti alur hidup sesuai dengan apa yang di takdirkan, yaitu mulai dilahirkan, mengarungi masa dewasa, masa tua dan diakhiri dengan kematian. Tahapan-tahapan perjalan hidup yang seperti itu sangat di mungkinkan dapat memberi pengaruh besar terhadap lingkungan, terutama bagi orang yang ada hubungan denganya, baik hubungan darah (nasab), maupun hubungan karena pernikahan ${ }^{1}$.

Lahirnya manusia pasti berdampak pada lahirnya hak dan kewajibannya sebagai individu yang berinteraksi dengan orang lain. Hubungan interaksi tersebut bisa dengan orang tuanya, kerabatnya,keluarganya, dan juga masyarakat lingkungannya. Sejak bayi, anak-anak, tamyiz, usia baligh, dan lanjut usia, manusia tidak pernah lepas dari hak dan kewajibannya. Manusia memiliki hak dan menanggung kewajiban baik sebagai pribadi, sebagai anggota keluarga, sebagai warga negara, dan sebagai pemeluk agama, yang harus taat, tunduk dan patuh terhadap syariat agama.

Demikian juga ketika manusia meninggal. Mereka juga membawa pengaruh dan akibat hukum kepada dirinya sendiri, keluarga, masyarakat dan lingkungannya. Adanya Kematian juga melahirkan kewajiban baru bagi manusia selainya yang masih hidup, di antaranya adalah mengurusi jenazah yang menjadi kewajiban bagi orang yang masih hidup, di samping akibat-akibat hukum lain yang

${ }^{1}$ Lihat Wiryono Projodikoro, Hukum Warisan di Indonesia, (Bandung: Sumur, 1983),hlm.13. 
salah satunya menyangkut hak para keluarga yang ditinggalkannya (ahli waris) terhadap seluruh harta yang ditinggalkan².

Dalam syariat Islam, seseorang yang wafat dan meninggalkan harta, hartanya harus diwariskan. Pembagian harta itu harus sesuai dengan hukum yang berlaku yaitu hukum waris. Hukum Waris adalah hukum yang mengatur pemindahan hak pemilikan harta peninggalan (tirkah) pewaris, menentukan siapa saja yang berhak menjadi ahli waris dan berapa bagian masing-masing 3 .

Hukum waris mengatur siapa saja yang berhak menjadi ahli waris yang mendapat bagian harta warisan, yang terhalang menerima warisan, berapa bagiannya masing-masing, bagaimana ketentuan pembagiannya, serta mengatur hak-hak yang berhubungan dengan pembagian warisan ${ }^{4}$.

Meskipun begitu, hukum waris terkadang menyisakan masalah dalam hal pembagiannya dan tidak jarang menimbulkan kebingungan bagi ahli waris. Hal ini, misalnya, terkait dengan persoalan-persoalan seputar sebab-sebab menerima warisan, halangan menerima warisan, dan hak-hak sebelum pembagian warisan.

Penulis mencoba memberikan pemecahan bagi ahli waris atau orang yang ditinggalkan ketika dalam keluarganya ada yang wafat dan meninggalkan harta. Sekalipun dalam pembagian waris telah ada petunjuk yang telah ditetapkan dalam al-Qur'an dan hadis, namun dalam pelaksanaannya sering ditemukan berbagai permasalahan, terutama jika jumlah ahli waris lebih dari seorang dan berasal dari berbagai latar belakang. Ketika ahli waris meng inginkan pembagian harta waris berdasarkan syariat Islam, tentu hal ini perlu disatukan pemahamnnya sehingga pembagian waris dapat dilakukan secara hukum Islam.

2 Lihat Suparman Usman dan Yusuf Somawinata, Figh Mawaris, (Jakarta: Gaya Media Pratama, 2002), hlm. 1

3 Pengertian hukum waris menurut ketentuan Kompilasi Hukum Islam (KHI) Pasal 171 Ayat 1, lihat Mulyadi, Hukum Waris Tanpa Wasiat, (Semarang: Badan Penerbit Universitas Diponegoro Semarang, 2008), hlm. 13.

${ }^{4}$ Ahmad Rofiq, Fiqh Mawaris, (Jakarta: PT. Raja Grafindo Persada, 2001), hlm. 4. 
Penulis juga memaparkan hukum kewarisan Islam dari sisi historiografi Islam, yaitu mencakup sejarah singkat tentang kewarisan Isalm, kewarisan pada masa pra-Islam, kewarisan pada masa awal Islam, dasar hukum kewarisan Islam. Sehingga dapat diketahui permasalahan permasalahan yang ada dalam kewarisan Islam itu sendiri, seperti sebab-sebab menerima warisan, halangan menerima warisan, dan hak-hak sebelum pembagian warisan.

\section{Sejarah Hukum Kewarisan Islam}

\section{Kewarisan Pada Masa Pra-Islam}

Masa pra-Islam dikenal juga dengan masa jahiliah, yaitu masa di mana bangsa Arab selalu melakukan peperangan dan bertindak tidak adil. Pada masa itu, kehidupan orang Arab ber gantung pada hasil perniagaan, jarahan, dan hasil rampasan perang dari bangsabangsa yang mereka taklukkan. Ketika itu, kekayaan berada di tangan laki-laki dewasa yang mampu dan memiliki kekuatan serta kekuasaan. Hal itu juga berlaku terhadap pembagian harta warisan. Maka, menjadi wajar jika harta warisan diberikan kepada laki-laki dewasa, bukan kepada perempuan dan anak-anak.

Pada masa jahilyah, pembagian harta warisan dilakukan dengan berpijak pada dua sistem, yaitu sistem keturunan dan sistem sebab5.

Salah satu yang menjadi Tradisi jahiliyah dalam pembagian harta warisan adalah bersifat patrilinear, di mana kaum perempuan dan anak-anak yang belum dewasa mereka terjegah untuk mendapatkan harta warisan, sekalipun mereka merupakan ahli waris dari yang telah meninggal 6 . Dengan itu sudah menjadi indikasi kuat bahwa pra-Islam keadaan bangsa Arab dalam masalah waritrsan mereka telah menjadikan kaum wanita tidak artinya.

Hal itu terjadi karena arab jahiliyah pada saat itu berdalih bahwa kaum wanita tidak mempunyai kekuatan untuk di ikut sertakan dalam berperang membela kaum dan sukunya. Bangsa Arab jahiliah dengan tegas menyatakan, "Bagaimana mungkin kami

${ }^{5}$ Muhammad Suhaili Sufyan, Fiqh Mawaris Praktis, (Bandung: Cita Pusaka Media Perintis, 2012), hal. 7.

6 Moh. Muhibbudin,dkk, Hukum Kewarisan Islam (Jakarta: Sinar Grafika, 2009), hlm. 32 
memberikan warisan (harta peninggalan kepada orang yang tidak bisa dan tidak pernah menunggangi kuda, tidak mampu memanggul senjata, serta tidak pula berperang melawan musuh." 7 Bahkan Mereka melarang keras dan megharamkan kaum wanita menerima harta warisan sebagaimana mereka mengharamkannya kepada anak-anak kecil ${ }^{8}$. Tidak sampai di situ, di antara mereka mengira bahwa kaum wanita yang ditinggal mati suaminya mereka termasuk harta yang dapat diwariskan dan diwarisi oleh para ahli waris suaminya.

Di masa jahiliyah (pra-islam), pembagian warisan dilakukan jika terdapat hubungan kekeluargaan/kerabat. Di antara mereka juga ada yang beranggapan bahwa harta warisan bisa diberikan terhadp mereka yang telah melakukan perjanjian prasetia, ${ }^{9}$ dan bias juga di berikan pada tabanni (anak-anak yang diadopsi /pengangkatan anak). Dari penjelasan di atas Dapat di tarik pemahaman bahwa, seseorang bisa mendapatkan harta warisan apabila10:

a. Ditemukan Pertalian Kekeluargaan/kekerabatan

Kekerabatan adalah hubungan nasab antara orang yang mewariskan dengan orang yang mewarisi yang disebabkan oleh kelahiran.

Hubungan kekerabatan yang melatar belakangi seorang dapat menerima warisan adalah jika merupakan laki laki yang mempunyai kekuatan dalam melakukan pembelaan, perlindungan untuk memelihara qabalah (persukuan) atau setidaknya yang di lindungi adalah keluarga mereka sendiri. Aturan ketat tersebut memberi dampak pada anak-anak yang belum dewasa dan kaum perempuan terjegah untuk mendapatkan warisan. Dua klompok ini terjegah untuk mendapatkan warisan hanya karena dinilai tidak mampu ikut serta terjun dalam medan perang dan berjuang bersama mereka yang kuat dan lebih dari itu mereka di pandang tidak cakap melakukan perbuatan hukum. karenanya, para ahli waris jahiliah dari golongan kerabat semuanya terdiri atas: (a) anak laki-laki, (b) saudara laki-laki,

\footnotetext{
7 Muhammad Ali al-Shabuni, Pembagian Waris Menurut Islam, terj. A.M Basmalah, (Gema Insani Press, 1995), hlm. x.

8 Ibid.,

${ }_{9}$ Sayyid Sabiq, Fiqh as-Sunnah, terj. (Semarang: Toha Putra, 1972), hlm. 3.

${ }^{10}$ Suparman Usman dan Yusuf Somawinata, Figh Mawaris....., hlm. 3
} 
(c) pa man, (d) anak-anak yang semuanya harus dewasa, dan (e) anak laki-laki paman.

Jika pewaris tidak mempunyai anak laki-laki dewasa, maka tirkahnya (harta peninggalannya) berhak di gterima oleh saudara laki-lakinya dengan catatan saudara tersebut juga sanggup berperang membela suku. ada hal lain yang di nilai jangkal dan mengherankan ialah bahwa seorang istri juga menjadi pusaka yang juga boleh di wariskan yang diwariskan, dengan catatan istri tersebut bukan ibu kandung yang mewarisi. Mereka juga memberi warisan kepada anak yang lahir di luar pernikahan ${ }^{11}$.

b. Sudah di gelarnya Janji Ikatan Prasetia

Definisi Janji prasetia adalah dorongan dan dukungan yang di dasari oleh kemauan bersama untuk saling membela jiwa raga dan kehormatan sesama. Dengan itu kaum wanita dan anak laki-laki terkesan disingkirkan sebab tidak mungkin terealisasi apabila pihakpihak yang berjanji adalah anak-anak yang belum dewasa, apalagi kaum wanita.

Adapun isi janji prasetia tersebut adalah: "Darahku darahmu, pertumpahan darahku pertumpahan darahmu, perjuanganku perjuanganmu, perangku perangmu damaiku damaimu, kamu mewarisi hartamu aku mewarisi hartamu, kamu dituntut darahmu karena aku dan aku dituntut darahku karena kamu, dan diwajibkan membayar denda sebagai ganti nyawaku, aku pun diwajibkan membayar denda sebagai pengganti nyawamu"12.

Akhir dari janji ikatan prasetia itu adalah apabila salah satu pihak meninggal dunia, maka pihak lain yang masih hidup berhak mendaptkan harta peninggalan partner-nya sebanyak $1 / 6$ bagian harta peninggalannya. Adapun sisa harta setelah dikurangi 1/6 dibagikan kepada ahli warisnya ${ }^{13}$.

c. tabanni (Pengangkatan Anak)

sebelumnya sudah di jelaskan bahwa pewarisan atas dasar kekarabatan, pewarisan atas nama ikatan janji prasetia, dan pewarisan atas nama tabanni (pengangkatan anak), itu semuanya bias

11 Ismuha, Penggantian Tempat Dalam Hukum Waris Menurut KUH Perdata, Hukum Adat dan Hukum Islam, (Darussalam: Bulan Bintang, 1978), hlm. 28

12 Fatchur Rahman, Ilmu Waris, (Bandung: Al-Ma'arif, 1981), hlm.14

${ }^{13}$ Moh. Muhibbudin,dkk, Hukum Kewarisan Islam, hlm. 34 
terlaksana dengan catatan mereka harus terdiri dari lelaki dewasa (yang mempunyai kekuatan cukup).

Adapun tendensi mereka untuk mengadakan janji prasetia dan pengangkatan anak adalah adanya dorongan kemauan bersama untuk saling membela jiwa raga dan kehormatan mereka serta memelihara dan mengembangkan harta kekayaan mereka. Hal itu tidak akan terealisasikan jika masih anak-anak atau perempuan. ${ }^{14}$

Sebelum diangkat menjadi Rasul, Nabi Muhammad saw mengangkat Zaid Ibn Haritsah menjadi anak angkatnya dan dikatakanlah Zaid bin Muhammad. Beliau mengangkat Zaid ini sebagai anaknya, sesudah Zaid dimerdekakan. Abu Hutzaifah Ibn 'Utbah mengangkat Salim menjadi anaknya dan dikatakanlah: Salim ibn Abu Huzaifah. ${ }^{15}$ Keadaan ini berlaku hingga turun surat alAhzab dibawah ini yang artinya: "Panggilah mereka (anak-anak angkat itu) dengan (memakai) nama bapak-bapak mereka; Itulah yang lebih adil pada sisi Allah, dan jika kamu tidak me ngetahui bapak-bapak mereka, Maka (panggilah me reka sebagai) saudara saudaramu seagama dan maulamaulamu. dan tidak ada dosa atasmu terhadap apa yang kamu khilaf padanya, tetapi (yang ada dosanya) apa yang disengaja oleh hatimu. Dan adalah Allah Maha Pengampun lagi Maha Penyayang". ${ }^{6}$ Ayat ini menegaskan bahwa, Nabi Muhammad saw bukanlah ayah dari seorang anak angkat (Zaid) dan anak-anak angkat tidaklah dapat dianggap sebagai anak sendiri, serta anak-anak angkat itu haruslah dibangsakan kepada ayah mereka sendiri.

2. Kewarisan pada Awal Islam

Kewarisan Pada awal Islam, pembagian sistem kewarisan masa jahiliah masih tetap berlaku hal itu berlanjut hingga turun ayat yang menegaskan bahwa para lelaki tanpa terkecuali baik dewasa ataupun bukan mereka semua bisa mendapatkan warisan dari tirkah (harta peninggalan orang tua dan kerabat-kerabat terdekat), tak kalah pentingnya ayat tersbut juga menegaskan bahwa kaum wanita tanpa terkecuali juaga berhak mendapaatkan warisan, untuk tirkah/peninggalan baik itu sedikit maupun banyak juga tetap harus

\footnotetext{
14 Ibid, hlm. 4

15 Teuku M.Hasbi ash-Shiddieqy, Figh Mawaris, (Semarang: Pustaka Risky Putra, 2011), hlm. 3

${ }^{16}$ Q.S. al-Ahzab (33): 5
} 
di wariskan. Sebagaimana Allah swt menjelaskan dalam al-Qur'an, yang artinya: "Bagi laki-laki ada hak bagian dari harta peninggalan kedua orang tua dan kerabatnya, dan bagi perempuan ada hak bagian (pula) dari harta peninggalan kedua orang tua dan kerabatnya, baik sedikit atau banyak menurut bahagian yang telah ditetapkan". ${ }^{17}$

Setelah ayat di atas turun turun, maka kebiasaan-kebiasaan pembagian warisan jahiliyah terhapus seperti tidak memberikan pusaka kepada perempuan dan anak-anak kecil.

Sementara pada saat islam abru masuk (awal Islam), nabi muhammad sudah menerapkan hukum kewarisan. hal itu bias di buktika dengan sejarah yaitu ketika nabi muhammad bersama para sahabatnya berimigrasi (hijrah) dari Mekkah menuju Madinah. Sesampainya di Madinah, nabi muhammad dan rombonganya di sambut gembira oleh penduduk Madinah saat itu begitu mereka sangat menghormati nabi dengan ditempatkan dirumah-rumah mereka, dicukupi segala keperluan hariannya, dilindungi jiwanya dari pengejaran kaum Quraisy, dan dibantu dalam menghadapi musuh-musuh yang menyerangnya.

Dalam rangka memperkuat dan mengabadikan tali persaudaraan, nabi muhammad menjadikan kesetiaan orang-orang yang ikut hijrah bersamnya sebagai salah satu yang melatar belakangi untuk saling mewarisi satu sama lain. Hal itu bias di lihat, seperti jika terdapat sahabat yang tidak mempunyai wali (ahli waris) yang ikut hijrah, maka harta peninggalannya diwarisi oleh walinya yang ikut hijrah. Ahli waris yang enggan hijrah ke Madinah tidak berhak mewarisi harta sedikitpun. Tetapi, jika ada sahabat yang tidak mempunyai wali yang ikut hijrah, maka harta peninggalannya dapat diwarisi oleh saudaranya dari penduduk Madinah yang menjadi wali karena ikatan persaudaraan. ${ }^{18}$

Dengan demikian dapat disimpulkan bahwa pada masa awal Islam seseorang dimungkinkan untuk mendapatkan harta warisan

${ }^{17}$ Q.S. an-Nisa' (4): 7

18 Ikatan persaudaraan disini adalah antara kaum Muhajirin dan kaum Anshar, yaitu orang-orang yang memberikanpertolongan kepada kaum muhajirin yang hijrah dari kota Mekkah ke kota Madinah. Lihat Ahmad Rafiq, Fiqh Mawaris...., hlm.7-8 
apabila Adanya pertalian kerabat, pengangkatan anak, hijrah dan ikatan persaudaraan. ${ }^{19}$

Penjelasan di diatas, dapat di simpulkan bahwa dalam kewarisan pada awal Islam, ikatan kekerabatan tnpa terkecuali mereka semua berhak menerima harta warisan baik dari klangan kaum laki-laki yang belum dewas ataupun kaum perempuan. Sementara hijrah seperti yang di contohkan rosul dan ikatan persaudaraan juga memungkinkan untuk mendapatkan harta warisan.

\section{Pelatakan Dasar-dasar Hukum KewarisanIslam}

Di lihat dari sejarahnya, hukum kewarisan Islam pada dasarnya bersumber kepada beberapa ayat al-Qur'an dan hadis Rasulullah yang terdiri dari ucapan, perbuatan dan hal-hal yang ditentukan Rasulullah. Baik dalam al-Qur'an maupun hadis-hadis Rasulullah, dasar hukum kewarisan ada tegas mengatur dan ada tersirat, bahkan kadang-kadang hanya berisi pokok pokoknya saja, yang paling banyak ditemui dasar atau sumber hukum kewarisan itu dalam surah an-Nisa',21 di samping surah lainnya sebagai pembantu. Penulis mencatat, ada 13 ayat yang menjelaskan tentang waris. Di dalam beberapa ayat, pengertian waris disamakan dengan pengertian wasiat.

Kalau dianalisis lebih lanjut, hukum waris memiliki dasar hukum (dalil) yang kuat, yaitu: al-Qur'an pada Surat an-Nisa': 7, 8, 9, 10, 11, 12, 13, 14, 33, 176, Surat Al-Anfal: 75, dan beberapa hadis Nabi SAW. Secara tegas, Allah menjanjikan surga bagi yang mengamalkan hukum ini melalui surat an-Nisa: 13, dan ancaman neraka bagi pelanggarnya melalui surat an-Nisa': 14. Adapun surat an-Nisa': 11, 12, dan 176 yang merupakan ayat-ayat waris utama, memberikan rincian ahli waris dan bagian masing-masing dalam angka pecahan, yaitu 1/2,1/4,1/8, 2/3,1/3, dan 1/6.

Dan Untuk mendapatkan gambaran yang jelas, penulis tidak dapat merinci satu persatu dari ayat tersebut namun sedikit penulis akan mengarahkan agar di lihat langsung pada bagian ayat-ayat sebagaiman di sebut.

\section{Penutup}

${ }^{19}$ Suparman Usman dan Yusuf Somawinata, Figh Mawaris....., hlm 4-5. 
Berdasarkan uraian diatas, dapat disimpulkan bahwa, secara historisitas, pembagian harta warisan sudah ada sebelum Islam (pra Islam). Sistem pewarisannya adalah sistem keturunan dan sistem sebab. Pembagian harta warisan bersifat patrilinear di mana anakanak yang belum dewasa dan perempuan tidak mendapatkan harta warisan, sekalipun mereka me rupakan ahli waris. Seseorang baru mendapatkan harta apabila memiliki pertalian kerabat, janji ikatan prasetia, dan pengangkatan anak. Sementara pada masa awal Islam seseorang bisa mendapatkan harta warisan apabila ada pertalian kerabat, pengangkatan anak, pertalian hijrah dan persaudaraan.

Dasar hukum kewarisan Islam bersumber pada al-Qur'an dan hadis. Dasar hukum kewarisan itu ada yang tegas, tersirat, bahkan ada yang hanya berisi pokok-pokoknya saja Dari sisi historis, hukum waris pra-Islam dan awal Islam dapat disebutkan bahwa: (1) Pewarisan baru terjadi jika ada sebab-sebab yang mengikat pewaris dengan ahli warisnya, seperti adanya perkawinan, kekerabatan, dan wala'; (2) Hal-hal yang dapat menggugurkan atau menghilangkan hak seseorang menerima warisan adalah perbudakan, pembunuhan, berlainan agama dan berlainan negara. Selain itu, ada yang berpendapat bahwa murtad dan hilang tanpa berita menghalangi seseorang untuk menerima warisan; dan (3) sebelum pembagian warisan ada beberapa hak yang harus dipenuhi terlebih dahulu, seperti; hak yang berkaitan dengan zat harta peninggalan, biaya perawatan jenazah, pelunasan hutang dan pemberian wasiat

\section{Daftar Pustaka}

Anwar, Desy,Kamus Lengkap Bahasa Indonesia Terbaru Dilengkapi Pedoman Umum Ejaan yang Disempurnakan, Surabaya: Amalia,2003.

Asrizal, Kafa'ah Bingkai Keharmonisan Rumah Tangga, Yogyakarta, Ladang Kata, 2015

Asrizal, dkk, Kajian Hukum Keluarga Dalam Perundan g-un dang an Indo nesia, Yogyakarta: Elpip, 2015.

Budiono, A. Rachmad, Pembaharuan Hukum Kewarisan Islam di Indonesia, Bandung: PT. Citra Aditya Bakti, 1999.

Dermawan, Hendro, dkk, Kamus Ilmiah Populer Lengkap, Dengan EYD dan Pembentukan 
Istilah Serta Akronim Bahasa Indonesia, cet.3, Yogyakarta: Bintang Cemerlang, 2011.

Doi, Abdur Rahman I., Hudud dan Kewarisan, Cet.1, Jakarta:PT. RajaGrafindo Persada, 1996.

Haries, Akhmad, Hukum Kewarisan Islam, Samarinda: P3M STAIN Samarinda, 2010.

Ismuha, Penggantian Tempat Dalam Hukum Waris Menurut KUH Perdata,

Hukum Adat dan Hukum Islam, Darussalam: Bulan Bintang, 1978.

Mughniyyah, Muhammad Jawwad, al-Fiqh 'ala al-Maz ahib alKhamsah, terj. Masykur A.B.,

Afif Muhammad, Idrus al-Kaff, Fiqh Lima Mazh ab: Ja'far, Hanafi, Malik i, Sya fi'i, Hambali, Jakarta: Lentera, 1996.

Muhibbudin, Moh., dkk, Hukum Kewarisan Islam, Jakarta: Sinar Grafika, 2009.

Mulyadi, Hukum Waris Tanpa Wasiat, Semarang: Badan Penerbit Universitas Diponegoro Semarang, 2008.

Parman, Ali, Kewarisan dalam al-Qur'an, Suatu Kajian Hukum denganPendekatan Tafsir Tematik, Jakarta: Raja Grafindo Persada, 1995

Rahman, Fatchur, Ilmu Waris, Bandung: al-Maarif, 1975.

Ramulyo, Idris, Perbandingan Hukum Kewarisan Islam, Jakarta: Sinar Grafika, 2004.

Rofiq, Ahmad, Fiqh Mawaris, Jakarta : PT. Raja GrafindoPersada, 2001.

Sabiq, Sayyid, Fiqh as-Sunnah,terj. Semarang: Toha Putra, 1972.

Shid dieq y, Te ungku M . H asbi ash, Fiqh Mawaris, Semarang: Pustaka Risky Putra,2011.

Sufyan, Muhammad Suhaili, Fiqh Mawaris Praktis, Bandung: Cita Pusaka Media Perintis, 2012

Syarifudin, Amir, Hukum Kewarisan Islam, Jakarta: Kencana Prenada Media Group, 2008.

Thalib, Sajuti, Hukum Kewarisan Islam di Indonesia, Jakarta: Bina Aksara, 1982

Umam, Dian Khairul, Fiqih Mawaris Cet.1, Bandung: CV. Pustaka Setia, 1999

Usman, Suparman dan Yusuf Somawinata, Fiqh Mawaris, Jakarta: Gaya Media Pratama, 2002. 